\title{
AMERICAN
}

\section{JOURNAL OF BOTANY}

\begin{tabular}{lll}
\hline \hline Vol. XIV JULY, I927 & No. 7
\end{tabular}

\section{A MONOGRAPHIC STUDY OF SPECIAL GROUPS OF THE WATER MOLDS II. LEPTOMITACEAE AND PYTHIOMORPHACEAE}

\author{
Bessie Bernice Kanouse \\ (Received for publication October 26, 1926) \\ FAMILY： LEPTOMITACEAE \\ Key to Genera and Species of the Leptomitaceate
}

I. Plant filamentous throughout, mycelium flaccid $\ldots \ldots \ldots \ldots \ldots \ldots \ldots \ldots \ldots$

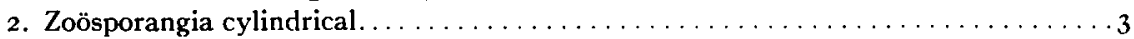

3. Zoösporangia formed directly from the terminal segment or from successive subterminal segments; zoöspores dipla-

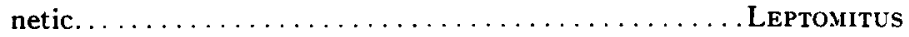

\section{L. lacteus}

3. Zoösporangia terminal or in whorls below the segments of the

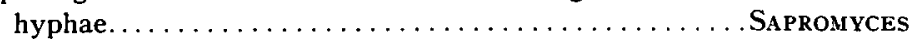

4. Antheridia of androgynous origin................ androgynous

4. Antheridia on long winding branches not associated with the oögonia............................ Reinschii

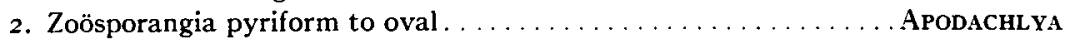

3. Oögonial wall punctate........................ punctata

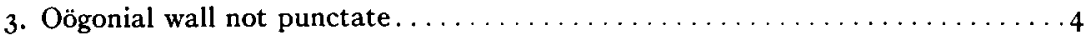

4. Segments 50-100 $\mu$ long, cylindrical. ................. brachynema

4. Segments $100-200 \mu$ long, cylindrical. .............. pirifera

I. Plant with greatly enlarged basal portion with filamentous branches...........

2. Fertile branches umbellately branched; exospore of mature oöspore

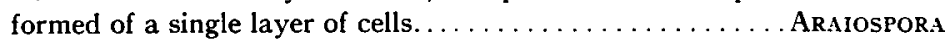

3. Spines on the spined sporangia arranged in one or two rows around the place of exit of the zoöspores.............. pulchra

3. Spines on the spined sporangia appearing over the entire surface of the sporangium.............................. spinosa

2. Fertile branches simple, sympodially branched; exospore of the mature oöspore having an areolate appearance, not cellular.. RHIPIDIUM

3. Pseudo-cell dichotomously branched, antheridia of androgynous origin.

3. Pseudo-cell elongate with or without apical expansion into

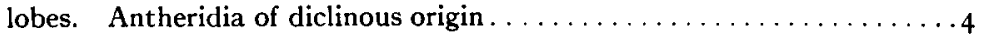

4. Sporangia and oögonia arranged in umbels on short subglobose branches.

[The Journal for June (14: 287-333) was issued July 7,1927 .] 
4. Sporangia borne terminally on long filamentous branches.......... 5

5. Fertilization tube entering the ooggonial wall at a region near the apex of the oögonium............... Thaxteri

5. Fertilization tube entering the oögonial wall at a region near the base of the ooggonium............... europaeum

Genus: LEPTOMITUS Agardh, Sylloge Alg. 47. 1824.-Apodya Cornu, Ann. Sci. Nat. Bot. V, 15: I4. 1872

Mycelium filamentous, slender, copiously branched, floccose, constricted into long segments by pseudo-septa. Sporangia formed directly from terminal segments of mycelium or formed from successive subterminal segments. Zoöspores diplanetic, biciliate. Sexual reproduction unknown.

\section{Leptomitus LaCteus (Roth) Agardh, Sylloge Alg. 47. 1824}

(See von Minden, Kryptogamenfl. Mark Brandenburg 5: 582 for literature.)

Vegetative plant attached directly to substratum without rhizoids, segmented, basal segments stout, up to $48 \mu$ thick, not easily distinguishable, constricted by evident constrictions into segments averaging 100-400 $\times$ 10-20 $\mu$, the final ones almost ten times as long as broad, but sometimes spherical or the constrictions lacking; branching abundant, usually under a constriction, monopodial, but of ten appearing dichotomous near the base; one to several cellulin bodies in each segment, mostly near the constrictions.

Asexual reproduction by means of zoösporangia, cylindrical like the segments but sometimes a little broader, solitary or a few in a row. Zoöspores oval, almost $12 \mu$ long, biciliate, cilia attached terminally, spores escaping from an opening usually at the side of the sporangium, swarming at once, sometimes diplanetic, on coming to rest developing a wall and germinating by a germ tube.

Sexual reproduction not known.

On fruits submerged in stagnant water, Ann Arbor, Michigan, December. Cosmopolitan. Known to occur in drainage from sugar factories, breweries, distilleries, slaughterhouses, city waste, etc., in stagnant and occasionally in clear waters.

The constrictions are sometimes lacking, according to von Minden (1. c.). This species was early known and described and there is an array of synonyms belonging to the older literature.

Adapted from von Minden.

Genus: APODACHLYA Pringsheim, Ber. Deutsch.'Bot. Ges. I : 289. 1883

Mycelium filamentous, floccose, copiously branched, constricted into rather regular segments by pseudo-septa. Rhizoids lacking. Mycelial wall turns faintly blue with chloriodid of zinc. Zoösporangia pyriform or broadly oval. Zoöspores formed in small numbers, sometimes encysting at the mouth of the sporangium in an Achlya-like manner, diplanetic, biciliate. Oögonia with one oöspore which nearly fills the oögonium. Oöspore containing one large oil drop. Antheridia unknown. 
Apodachlya Pirifera Zopf, Nov. Acta Acad. Leop. 52: 362.

Pl. 2I, figs. I-2I. 1888

Leptomitus piriferus Zopf. Die Pilze, Schenk's Handbuch 4: 299.Kryptogamenfl. Mark Brandenburg 5: 585, fig. I 5, $a-b, 580$.

Vegetative plant woven over the surface of the substratum, lacking rhizoids, hyphae copiously branched, segmented, basal segments becoming stout, smaller toward the ends, segments long cylindrical.

Asexual reproduction by means of zoösporangia which are terminal, mostly pyriform, but also oval to fusiform, I2-24 $\times 12-20 \mu$, with short terminal or sometimes laterally placed exit-papilla; sporangia becoming sympodially arranged, as many as twelve sporangia sometimes so placed. Zoöspores becoming grouped in a hollow sphere at the mouth of the sporangium immediately on emergence from the sporangium.

Sexual reproduction by means of oögonia which are mostly terminal on long branches, seldom on short segmented side branches or intercalary; spherical, with a double (?) membrane, at maturity with colorless contents and a gigantic oil drop. Antheridia unknown.

On decaying Characeae (Zopf).

Doubtless the so-called "resting spores" of Zopf (1. c.) are here, as elsewhere, composed of more than two wall layers.

Tiesenhausen (35) describes a variety of this species which he calls Apodachlya pirifera var. macrosporangia which differs chiefly in having hyphae of greater diameter and longer sporangia, measuring 37-50 $\mu$ in length. On needles of Picea excelsa submerged in water. Switzerland.

Adapted from von Minden.

Apodachlya punctata von Minden, Kryptogamenfl. Mark

Brandenburg 5: 586, fig. 15c-d. 1912

Vegetative plant woven over the surface of the substratum, rhizoids lacking, filamentous, segmented, branched.

Asexual reproduction by means of zoösporangia which are formed terminally but become sympodially arranged by the continuation of the growth of the branchlets, of ten in quite abundant groups, clavate, oval to pyriform or subglobose, opening usually at the side of the sporangium, sometimes near the base of the sporangium. Zoöspores never or seldom forming a hollow sphere, usually swimming directly on emerging from the sporangium.

Sexual reproduction by means of oögonia ("resting spores") formed either at the ends of long hyphae or on mostly strongly reduced segments or branches.

On decaying plant substrata, twigs, stems, etc., Breslau and Hamburg (von Minden).

Adapted from von Minden.

Von Minden remarks that the "resting spore" is similar to that of $A$. pirifera but distinct by the finely regularly punctate inner oögonial wall. Coker (7) in commenting on A. punctata says, "Minden's species is more than doubtful." The punctate wall of the oögonia is believed by Coker to be merely an emulsion of the protoplasmic contents of the oögonia and 
not to be a definite morphological character. We have included it because of our belief that von Minden is sufficiently experienced to know what he saw.

Apodachi,ya brachynema (Hildebr.) Pringsh., Ber. Deutsch. Bot.

Ges. I : 289. I 883

Leptomitus brachynema Hildebr., Jahrb. Wiss. Bot. 6: 26I. Pl. I5, figs. 13-23.-A podya brachynema (Hildebr.) Cornu, Ann. Sci. Nat. Bot. V, I5: I4.-Kryptogamenfl. Mark Brandenburg 5: 587.-The Saprolegniaceae, 173, Pl. 59, figs. I-22.

Vegetative plant not attached to substratum by rhizoids, entirely filamentous, floccose, branching copiously, segmented by constrictions which are accompanied by pseudo-septa composed of cellulin; septa in old mycelium forming complete separation between the adjacent segments. Cellulin bodies one to several in each segment; segments 50-100 $\times 8-20 \mu$, averaging $60 \times$ I $2 \mu$, variable in size and shape, becoming longer, dumbbell-shaped or in chains of subglobose Monilia-like cells. Branches one to several arising usually from the distal ends of segments, forming obtuse angles with the main filament. Cell membranes tardily turning faintly blue with chloriodid of zinc.

Asexual reproduction by means of zoösporangia borne terminally at the ends of long hyphae or at the ends of lateral branches which are composed of few to many long segments, subglobose, ovate-elliptic, oval to pyriform, $44-76 \times 30-44 \mu$, thin-walled. Exit-papilla not conspicuous. Zoöspores few in number, swimming directly from the sporangia without encysting near the place of exit, I2-I4 $\mu$, diplanetic (Coker).

Sexual reproduction by means of oögonia borne singly at the ends of short lateral branches composed of a few Monilia-like segments. Oöspores single, filling the oögonia, surrounded by three walls, the outer and inner of which are thin, the middle one thick, hyaline, of homogeneous consistency. Contents of old oöspores evenly and finely granular, disposed at the periphery of the spore together with many small, regularly placed oil droplets, the center of the spore consisting of a large vacuole and one or two large oil droplets; spherical, 20-40 $\mu$. Antheridia unknown.

On submerged decaying apples and Crataegus fruits, Ann Arbor, Michigan. March, November. On immersed decaying stems, Bonn (Hildebrand); on termite ant, North Carolina (Coker); Massachusetts (Thaxter).

From the original. Pure culture studies were made by the writer. Coker's interpretation of the so-called "resting spores" being true oögonia is undoubtedly correct. The fact that three distinct walls are present surrounding a mature oöspore seems to indicate that these bodies should not be called " resting spores."

The writer has also observed the hypogenous cells that Coker has described but the latter's supposition that such cells are probably antheridia needs further elucidation or cytological proof. Attention is here called to the quite similar hypogenous cells in Saprolegnia hypogena de Bary, in which, as Kauffman (I7) has shown, the hypogenous cell is not used directly 
as an antheridium, for the antheridial filaments were found capable of originating either from the hypogenous cell or from any part of the plant. The apical extensions into the oögonium were considered non-functional. The observations of Coker raise the question whether the several hypogenous cells from which he found the protoplasm passing into the young oögonium, presumably through the perforated cellulin masses which usually exist at the constrictions, do not merely serve as feeding organs for the enlargement of the oögonium during its development. It is, of course, conceivable that these pseudo-cells might be originating sources of antheridial filaments, but as yet there is no such evidence.

Tiesenhausen (35) described a variety as A. brachynema var. major which differs chiefly in having hyphae of a greater diameter as well as sporangia of greater length. This was found in a slimy mass at the surface of the water. Switzerland.

GeNus: SAPROMYCES Fritsch, Österr. Bot. Zeitschr. 43: 420 . I893

Naegelia Reinsch, Jahrb. Wiss. Bot. II : 298.-Naegeliella Schröter, Engler and Prantl Nat. Pfl. Fam. I: 103.

Mycelium filamentous with a slightly differentiated basal pseudo-cell with few or no rhizoids, constricted at the pseudo-septa, branched at the apex of each successive segment to form a spreading structure, which is often extensive. Walls turn blue with chloriodid of zinc. Zoösporangia generally formed at the branching apex of each segment, or terminal, or in whorls at the constrictions, elongate, subcylindrical to clavate. Zoöspores either emerging and escaping directly or sometimes emerging into a vesicular membrane which ruptures almost at once, apparently monoplanetic, biciliate. Oögonia subglobose or pyriform, narrowed toward the pedicelled base, which is differentiated from the hyphae by a cellulin plug. Oöspore solitary, spherical with scanty periplasm. Antheridial branches of androgynous or heterogynous origin, arising distally from the segments, the portion immediately below the antheridium twisted on itself. Antheridium oblong, curved, penetrating the oögonia at the apices, indenting the walls; fertilization tube present.

A somewhat confusing inconsistency has appeared in the literature concerning the escape of the zoöspores and the presence or absence of a vesicular, extruded membrane at the time of the zoöspore formation in this genus. Petersen (27) misquotes Thaxter, while Coker (7) quotes Petersen so that the result is misguiding, to say the least. Thaxter in his first paper (31) clearly states that "there was no indication of any process similar to that described by Cornu in Rhipidium, where the contents of the sporangium is said to be discharged simultaneously as a mass of zoöspores which are then set free by the rupture of a thin surrounding membrane." Turning now to Thaxter's second paper in which he discusses Sapromyces (34, p. 323), we find Thaxter reporting as follows: "The species previously described ( $S$. Reinschii) has been observed by the writer in great abundance and in perfect condition since the publication of the note above mentioned, and in specimens growing under favorable conditions 
the emission of the zoöspores has been seen to be similar to that of Rhipidium except that the membrane surrounding the emerging spore mass is ruptured almost immediately, so that all but a small number of the spores escape in the usual way through the open mouth of the sporangium."

\section{Sapromyces Reinschil (Schröter) Fritsch, Österr. Bot. Zeitschr.} 43: 420. 1893

Bot. Gaz. r9: 54. Pl. 5, figs. I-9.-Hyphomycetarum nov. gen. Reinsch, Contrib. ad Algol et Fungol I: Pl. I4.-Naegelia sp. I-2 Reinsch, Jahrb. Wiss. Bot. II : 298. Pl. I5, figs. I-I I.-Sapromyces dubius Fritsch (1. c.).Kryptogamenfl. Mark Brandenburg 5: 589, fig. I I.-Fischer, Phycomycetes, in Rabenh. Kryptogamenfl. Pilze I, pt. 4: 377.-Naegeliella Reinschii Schröter, Engler and Prantl Nat. Pfl. Fam. I: Io3.-Ann. Mycol. 8: 527, fig. 4 (b, $c$ and $d$ ), and fig. 5.-Rhipidium elongatum Cornu, Ann. Sci. Nat. Bot. V, 15: I5.

Vegetative plant attached to substratum directly without rhizoids or with only a few weakly developed ones, composed of numerous successive nearly cylindrical segments arising one to several from scarcely differentiated basal segments which measure $450 \times 10-15 \mu$ or longer, each segment producing distally one to several similar segments; constrictions between segments usually closed with cellulin plugs or more commonly without such pseudo-septa, the contents of successive segments being in direct communication with one another.

Asexual reproduction by means of zoösporangia which are borne singly or in whorls of two to six at the free end of a branch, or on the segments at the constrictions; subcylindrical to elongate-elliptical, $35^{-200} \times 20-25 \mu$. Zoöspores escaping through a terminal pore or the whole zoöspore mass emerging and surrounded by a vesicular membrane which is immediately ruptured, when emerging separately with the ciliated end backward, kidney-shaped, with two cilia arising from a depression at the side, apparently monoplanetic.

Sexual reproduction by means of oögonia and antheridia. Oögonia borne terminally or laterally like the sporangia and often associated with them, sub-spherical to pyriform, 26-40 $\times 32-55 \mu$, becoming covered at maturity by a brown, flaky incrustation disposed transversely, and containing a single, nearly smooth, spherical oöspore, $20-30 \mu$ in diameter, with thick yellowish membrane. Antheridia borne like the ooggonia but not associated with them, on long winding twisting branches irregularly cylindrical, abruptly distinguished from the antheridial branch, sometimes divided by a septum, penetrating the oögonium at its apex by a beak-like pollinodium.

On Viscum stems, on algae, Germany (Reinsch); on cones and twigs of Pinus, Maine (Thaxter); on old branches of fir, Denmark (Petersen); on pine twigs, Germany (von Minden); in North Carolina (Couch); in Switzerland (Tiesenhausen). Von Minden says that it was also found in Germany by Claussen.

Adapted from Thaxter. Coker (7) has given a detailed account of the various methods of spore discharge in this species, from which can be inferred the extreme sensitiveness of this process to external conditions. 
Sa Promyces androgynous Thaxter, Bot. Gaz. 21: 329. Pl. 22, figs. I6-19. I896.-Kryptogamenf. Mark Brandenburg 5: 59 I

Vegetative plant attached directly to substratum without rhizoidal outgrowths. Like $S$. Reinschii except somewhat smaller, total length 500-1000 $\mu$.

Asexual reproduction by zoösporangia, $75 \times 26 \mu$.

Sexual reproduction by means of oögonia and antheridia. Oögonia pyriform, 35-50 $\times 27-30 \mu$, sometimes encrusted by a blackish scaly deposit. Oöspores spherical, $20-26 \mu$, the thick colorless wall more or less modified by the presence of elevations which sometimes give a roughly undulate outline. Antheridial branches of androgynous origin, arising close to the base of the oögonium from the same segment, a spiral twist usually present below the antheridium which applies itself to the apex of the ooggonium and is in form similar to that of S. Reinschii.

On submerged sticks, Massachusetts (Thaxter).

Adapted from Thaxter.

Genus: RHIPIDIUM Cornu, Bull. Soc. Bot. France 18: 53. 1871.Ann. Sci. Nat. Bot. V, I5: 15. 1872

Mycelium differentiated into a monstrously developed basal pseudo-cell which is distally lobed or branched, with numerous rhizoids at its base. Wall greatly thickened, turning blue with chloriodid of zinc. Branches becoming sympodially branched below the originally terminal sporangia, segmented by a constriction at their point of origin, seated on a short pedicel due to constriction. Zoöspores emerging from the sporangia in a cylindrical mass surrounded by a vesicular membrane and surmounted by a true papilla of dehiscence, biciliate, monoplanetic. Oögonia usually borne terminally on a pedicel formed by constriction, differentiated into oöplasm and periplasm, globose or subglobose; oöspore during its development connected with the oögonial wall by radial periplasmic strands, at maturity free from the oögonial wall and sculptured in an areolate manner. Antheridia usually small, applied near the base of the oögonia (at the apex in $R$. Thaxteri). Fertilization tube present and formed by the antheridium.

Rhipidium eUropaeum (Cornu) von Minden, Kryptogamenfl. Mark Brandenburg 5: 597. Fig. $9 a-e$. 1912

Rhipidium continuum and $R$. interruptum Cornu, Ann. Sci. Nat. Bot. V, 15: I5.-van Tieghem, Traité Bot. 1024, fig. 61 7.-Falck, Mycol. Untersuch. 2: 187. Pl. 2.-Kanouse, Mich. Acad. Sci. Arts and Lett. 5: 105. Pl. I, fig. 2 .

Vegetative plant attached to substratum by means of numerous penetrating branched thizoids. Thallus extremely variable in shape and size; sometimes the disk-shaped basal portion with its broad lobes arises from a narrow stalk-like base, its main portion measuring up to $800 \mu$ wide, its lobes up to $150 \mu$ wide; more of ten elongated, subcylindrical to vase-shaped or with a flabelliform outline, varying between 250 and $950 \mu$ long, and from Io-I50 $\mu$ wide, lobes broad, rounded to subtruncate at apex. Wall up, to $20 \mu$ thick, outer surface often rough-scaly, turning to "litho-purple" (Ridg.) with chloriodid of zinc. Branches abundant, arising from the upper periphery of the basal portion and its lobes, sometimes from any 
portion, $50-500 \mu$ long $\times 7^{-12} \mu$ wide, generally each branch at point of origin with pedicel-like constriction, above which a bulbous enlargement occurs, the constrictions being repeated along the filaments, or scanty, or absent, very rarely branching a second time.

Asexual reproduction by means of zoösporangia which are borne terminally and singly at ends of branches, each with a pedicel-like subsporangial constriction, branches from below the sporangia giving the effect of a sympodial arrangement, sometimes several so arranged; sporangia of two kinds, thick-walled and not collapsing after being emptied, or with thin, collapsible membranes, variable in size and shape, usually oval, broader at base, sometimes almost spherical or ellipsoid, $50-65 \times 27-38 \mu$. Zoöspores biciliate, monoplanetic, $12-13 \mu$, spherical, escaping in a cylindrical vesicle which precedes in part the escape of the spore mass, and which is accompanied by the lifting off of the dehiscent papilla, spores immediately breaking through the vesicle and swimming away.

Sexual reproduction by means of oögonia and antheridia. Oögonia borne terminally on the ends of the branches, provided with suboögonial pedicel-like constrictions, globose, $50-60 \mu$ in diameter; oögonial wall quite thick, smooth. Oöspore solitary, spherical, surrounded by a thin inner wall and by a remarkably thick exospore up to I $5 \mu$ thick, with a surface which is areolate and substellate from points and ridges. Antheridial branches of diclinous origin, slender, winding, sometimes branched. Antheridia small $(19 \times 15 \mu)$ spherical or clavate, applied at the base of the oögonia and penetrating the oögonia by developing a fertilization tube.

On submerged fruits in lakes, ponds and ditches in stagnant water, March to December. Ann Arbor, Michigan. On surface of decaying fruits, Hamburg and Breslau, Germany (von Minden); in France (Cornu); in Denmark (Petersen).

(a) A form which is figured by von Minden (26, Pl. 2, fig. Io, and text figs. 9-10) was also observed by me at Ann Arbor. The plant consists of a thalloid placque, usually disk-shaped, appressed to the substratum, attached by rhizoids, provided on its periphery with very short sporangiabearing stunted branches. Zoösporangia typical, usually smaller. Sexual reproductive organs never observed.

(b) Forma attenuata f. nov. (Plate XLVIII).

Vegetative plant very slender, attached by long, slender, penetrating rhizoids. Basal portion very long and narrowly subcylindrical, simple or sometimes once forked, $2000-3200 \times 20-50 \mu$, wall relatively thick, 7-IO $\mu$, protoplasm hyaline, including numerous oil globules upward. Branches scanty, arising from the apex of the main portion, differentiated at point of origin by pedicel-like constrictions which are provided with perforated cellulin deposits, very slender and flexible, 200-500 $\times 6-9 \mu$.

Asexual and sexual reproduction typical.

On decaying Crataegus and apple fruits submerged in stagnant water. Ann Arbor, Michigan, October and November, I925.

Unique by its appearance on the substratum where it forms a grayishwhite, interwoven, thick, dense mat, while all other specimens are tufted or solitary in habit. 

Rhipidium Americanum Thaxter, Bot. Gaz. 2 I : 320. Pl. 22, figs. I-I 5. I 896

Kryptogamenfl. Mark Brandenburg 5：599; Mycol. Untersuch. 2: 188. Pl. 3, fig. 2 I.

Vegetative plant attached to substratum by means of copious penetrating rhizoids. Basal portion variable in form and size. $75-400 \mu$ above, more or less regularly one or more times successively dichotomously branched or lobed, the lobes or branches erect or spreading in a radiate fashion; branches numerous, 50-800 $\times 12-14 \mu$, arising from the upper or external edges of the basal portion, sometimes consisting of two or three subclavate segments, arising from the basal cell by pedicel-like constrictions.

Asexual reproduction by means of zoösporangia originally terminal, one to four succeeding one another on a single filament, rarely two or three borne terminally, varying in form, typically ovoid, 30-90 $\times 20-46 \mu$ (30-86 $\times 20-27 \mu$, Thaxter), apex bluntly rounded. Zoöspores biciliate, composed of coarse refractive granular protoplasm, emerging from the sporangium in a cylindrical mass surrounded by a thin membrane and surmounted by a papilla of dehiscence, monoplanetic, IO-I $2 \mu$.

Sexual reproduction by means of oögonia and antheridia; oögonia borne terminally on branches with suboögonial pedicel-like constrictions like those of the sporangia, spherical, $40-55 \mu$ in diameter; oöspore solitary, colorless, thick-walled, $30-45 \mu$ in diameter, with exospore elevated in a series of anastomosing ridges which give the spore an irregularly stellate outline; antheridial branches arising from the same branch that bears the oögonium, and immediately beneath it, short, slender; antheridium small, I4 $\mu$, rounded, applied close to the base of the oögonium. Fertilization tube penetrating the oögonium.

On decaying submerged fruits of Crataegus, rose and apple. Ann Arbor, Michigan. March to December. On various decaying vegetable substances, Massachusetts, and Maine (Thaxter); Hamburg (von Minden).

This fungus appears to be a common plant in the vicinity of Ann Arbor. It has been obtained of ten growing on the same fruits with other rhipidiums and with blastocladias. It usually forms a dense tuft on the fruit surfaces, but sometimes grows singly.

Rhipidium Thaxteri von Minden, Kryptogamenfl. Mark Brandenburg

$$
\text { 5: 600. I9I2 }
$$

Falck's Mycol. Untersuch. 2: 188. Pl. 3, figs. 22-24.

Vegetative plant attached to substratum by means of numerous branching penetrating rhizoids. Basal portion of ten of large size, sometimes $800 \mu$ broad with lobes up to $200 \mu$ wide, or at times more cylindrical, quite thick-walled. Branches arising from the basal cell, of uniform thickness, about 7-II $\mu$, floating, somewhat flexuous, nearly always without intercalary segments, but constricted at point of origin and below the reproductive organs.

Asexual reproduction by means of zoösporangia, one or several formed terminally on a branch and usually also on very short lateral and distant supports which are acquired by a sympodial arrangement due to continued growth of the branch from a region just below the mature sporangium. 
Sporangia long-ellipsoid, $50-55 \times 20-35 \mu$, opening at the apex; zoöspores escaping like those in $R$. europaeum and of similar form and structure.

Sexual reproduction by means of oögonia and antheridia. Oögonia borne on short somewhat spirally twisted stalks arising from the basal portion and gradually widening upward without suboögonial constriction, large, globose but mostly somewhat pyriform, 57-62 $\times 45-57 \mu$, wall slightly rough-wrinkled at maturity. Oöspore solitary, large, thick-walled with stellar ridged exospore. Antheridial branches arising from the basal stalk, of diclinous origin, long-winding, branched, growing to the apex of the oögonium. Antheridial filaments slender, irregularly branched, arising mostly from the basal portion of the thallus among the other branches. Antheridia unusually large, 50-70 $\times 7-1$ I $\mu$, irregularly clavate, applied by their whole length to the oögonium, coalescing with the oögonial wall at its apex where it develops a penetrating fertilization tube.

On decaying fruits, Hamburg, Germany (von Minden).

Adapted from von Minden.

\section{RHIPIDIUM PARTHENOSPORUM SP. NOV.}

Vegetative plant attached to the substratum by means of a few rhizoids. Basal portion elongated and slender, once or twice forked, 800-1000 $\mu$ long by $25^{-30} \mu$ wide; wall smooth, hyaline, not becoming greatly thickened, 7-10 $\mu$ thick; protoplasmic contents hyaline, coarsely granular and containing many oil globules. Branches very short, arranged in umbels, constricted pedicel-like at point of origin, enlarged in an ellipsoid or globose manner above this constricted portion which bears the reproductive organs, constrictions with plug-like cellulin deposits.

Asexual reproduction by means of sporangia which are borne in umbellate clusters on the short branches, ellipsoid, thin-walled, 50-60 $\times 34-50 \mu$, clusters few to several. Zoöspore formation unknown.

Sexual reproduction by means of oögonia in which are formed solitary, parthenogenetic oöspores borne in umbellate clusters on the short branches, with suboögonial pedicel-like constrictions, spherical, thin-walled, smooth, $52-54 \mu$ in diameter; during development differentiated into oöplasm and periplasm, the latter with strongly marked radiating periplasmic strands so as to appear cellular; mature oögonia not seen. Antheridia apparently lacking.

On decaying apple, immersed in the shore water of a lake. April. Type collected by Bessie B. Kanouse near Ann Arbor, Michigan.

There is little doubt but that this plant is a definite species although unfortunately it has not been found in sufficient quantity to determine all its characters, nor has its artificial culture hitherto been a success.

It is sharply marked by the manner in which it bears the sporangial and oögonial clusters on the same plant, but these organs were never mixed in any of the clusters in the plants seen. Stunted plants of related species may show similar reduction of the branches, but in such cases the basal portion is equally reduced, while here the short branches bearing the reproductive organs occur regularly on what must be considered as normal plants. 
Genus: ARAIOSPORA ${ }^{1}$ Thaxter, Bot. Gaz. 2: 326.1896

Mycelium forming a large cylindrical pseudo-cell bearing rhizoids and branches. Branches segmented, arising in whorls from the distal end, repeatedly umbellately branched, pseudo-cells cylindrical or nearly so. Zoösporangia of two kinds, the one smooth, the other differently shaped and furnished with prominent spines. Zoöspores emerging in a mass at first surrounded by a thin membrane which ruptures almost immediately, biciliate, monoplanetic. Oögonia borne in whorls or umbels, often associated with the zoösporangia, spherical, separated from the segments like the zoösporangia by a constriction. Oöspore solitary, exospore surrounded at maturity by a row of cell-like compartments of periplasmic origin. Antheridial branches arising from special segments, simple or branched. Antheridia small, rounded, applied close to the base of the oögonium. Fertilization tube formed by the oögonium from within.

Araiospora SPinosa (Cornu) Thaxter, Bot. Gaz. 21 : 590. 1896

Rhipidium spinosum Cornu, Ann. Sci. Nat. Bot. V, I5: I4. Pl. 5, figs. I-9.-Kryptogamenfl. Mark Brandenburg 5: 593, figs. Ioa-c.-Mycol. Untersuch. 2: 157 . Pl. I, figs. I-8.

Vegetative plant attached to substratum by numerous penetrating rhizoids. Basal portion variable, of ten large, broadly cylindrical, 800 $\times \mathrm{I} 60 \mu$, with stout walls, or in feeble plants thinner; at its upper end provided with numerous stout cell-like branches usually repeatedly umbellately branched, on which the branching may be repeated; constrictions only at the origin of the branches and at point just below the reproductive organs, seldom elsewhere. Primary branches $780 \times 76-96 \mu$.

Asexual reproduction by means of zoösporangia of two kinds. These are borne in whorls with two to six in a whorl; the smooth-walled sporangia more or less long-ellipsoid, 90-150 $\times 45^{-60} \mu$; the spined sporangia oval, 100-150 $\times 40-80 \mu$, or broadly ellipsoid, with mostly solid pointed spines which are straight or slightly bent, either stiff or weak, usually in two rows in an indefinite number, often arranged about the exit-papilla, size variable, $60-70 \times 9 \mu$. Zoöspores in both sporangia of the same form, kidney-shaped with two cilia attached laterally, monoplanetic.

Sexual reproduction by means of oögonia and antheridia. Oögonia formed in a clustered fashion on a constricted pedicel, spherical, wall smooth, brown. Oöspore solitary, not completely filling the oögonium, spherical, surrounded with a thick envelope of cellular structure. Antheridia borne on long, thin branches of diclinous origin, relatively large, curved-cylindrical, of ten encircling the oögonial wall.

On decaying immersed twigs of oak and of alder, upon decaying rhizoids of water lily, Breslau and Hamburg, Germany (von Minden); probably also in France (Cornu).

Adapted from von Minden.

'See also Lindner, David H. A new species of Araiospora from British Guinea. Mycologia I8: $172-178$. 1926. 
Araiospora pulchra Thaxter, Bot. Gaz. 21: 328. Pl. 23, figs. 20-25. I 896

Proc. Boston Soc. Nat. Hist. 3I: 21 I-245--Kryptogamenfl. Mark Brandenburg 5: 598 .

Vegetative plant attached to substratum by means of rhizoids. Basal portion variously developed, usually large, I000-I500 $\times 25^{-50} \mu$, subcylindrical, the ramiferous extremity subconical, bearing numerous acropleurogenous branches in a more or less distinctly umbellate fashion and separated from it by the usual constrictions. Branches composed of more or less cylindrical segments and repeatedly umbellately branched, the segments subcylindrical becoming more slender and usually longer as they succeed one another, branches long, $275^{-275} \mu$.

Asexual reproduction by means of zoösporangia of two types. Zoösporangia borne in whorls or umbels; one type subcylindrical or broadly clavate, smooth, $120-275 \times 30^{-} 35 \mu$; the second type broadly oval to pyriform and furnished with large spines radiating in all directions, but sometimes short and stout and confined to the distal extremity. Spinose forms $48-70 \times 45^{-60} \mu$. Spines $10-35 \mu$ long. Zoöspores escaping through a wide exit-papilla, finely granular, biciliate, monoplanetic, emerging in a mass at first surrounded by a thin membrane which ruptures almost immediately.

Sexual reproduction by means of oögonia and antheridia. Oögonia borne like the sporangia, the constricted pedicels which separate them from the segments very short, $50-60 \mu$. Oöspores spherical, $35-45 \mu$ thick, wall colorless, surrounded by a single layer of more or less hexagonal, peripheral cells derived from the periplasm, cells about $7-10 \mu$ in diameter. Antheridial branches arising from special segments, simple or branched, the small rounded antheridia applying themselves close to the base of the oögonium. Fertilization tube initiated and formed by the oögonium.

On sticks, Massachusetts (Thaxter).

Adapted from Thaxter (1. c.) and from King (I8).

\section{Phylogenetic Considerations}

All of the systematic arrangements that have been suggested for this group of fungi fall short of presenting an adequate picture of the phylogeny of the water molds. The following arrangement is proposed in the belief that it indicates the natural affinities existing between the several orders, and it is founded upon the morphological facts as we know them at present. The interpretation involves the erection of a new order, the LePTomitales. The following diagram presents the scheme of this new phylogenetic arrangement. It is succeeded by a discussion of the relation of the orders and of their integral parts, together with a presentation of the significant facts that lend support to this proposal. 


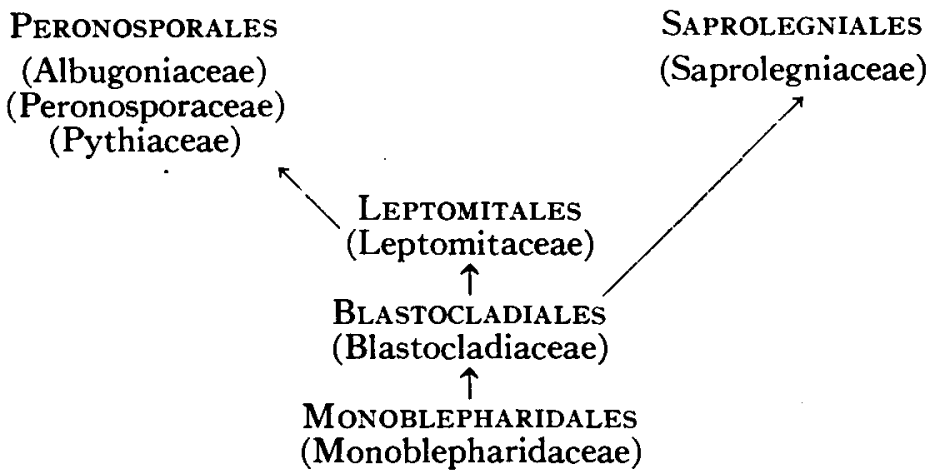

As is shown in the diagram, the relationship of the Leptomitales at the lower limit is with the Monoblepharidales through the Blastocladiales, while at the upper limit it is with the Peronosporales.

The most recent and by far the most comprehensive criticism of the older taxonomic views is given by Butler (4). He summarizes the several important phylogenetic schemes that have been proposed for the classification of the Oömycetes since the time of de Bary (II), and makes clear that not only de Bary, but Brefeld and Fischer were mistaken in placing Pythium as the starting point in the phylogenetic line of this group of fungi. Butler's discussion is centered primarily around the genus Pythium with a strong defense for the belief that this genus represents an advanced rather than a primitive position in relation to the other Oömycetes. He discusses views held by the previous investigators concerning the position of the family Leptomitaceae and concludes by saying "we are justified in considering that a derivation of the main families through Monoblepharis and the Leptomitaceae has most in its favor."

This view was reëmphasized and strengthened by Butler (5) in a later paper on Allomyces, a genus included by him in the Leptomitaceae.

Thus Butler has paved the way in a logical and clear manner for the further reorganization of the Leptomitaceae and Blastocladiaceae into the arrangement here proposed. He has not, however, suggested any classification that would correct some of the difficulties associated with the two families mentioned above.

These families have usually been included in the order Saprolegniales. Thaxter is the only botanist who has intimated any other possible relationship for the Leptomitaceae. He included the family in that order but with the following qualification: "Should the family be united with any other, it must be with the Pythiaceae, if we recognize them as distinct from the Peronosporaceae, or with the latter if we do not." Since he did not make clear his conception of the position of the Pythiaceae, his conclusion remains uncertain. Only indirectly does he suggest a complete removal of the Leptomitaceae from the Saprolegniales. If, as was suggested, that family were united with the Pythiaceae, this would not necessarily mean its 
[Vol. 14,

exclusion from the Saprolegniales, as the Pythiaceae were included in the Saprolegniales by Schröter. On the other hand, if the Pythiaceae were considered a family of the Peronosporales, as was proposed by de Bary (I I), it would mean a complete removal from the Saprolegniales.

A brief summary of the characters of the orders already established is necessary before the similarities and differences between the old orders and the proposed new order Leptomitales can be fully recognized.

The Peronosporales comprise a group of fungi that are commonly parasitic; they may reproduce asexually by conidia; sexual reproduction is by means of oögonia, and antheridia with fertilization tubes. The oögonia contain single oöspores surrounded by periplasm.

The Saprolegniales are a group of water-inhabiting fungi commonly saprophytic. They reproduce asexually by means of zoöspores and by gemmae. Sexual reproduction is by means of oögonia in which many oöspores without periplasm are formed, and antheridia with fertilization tubes.

We shall now consider critically the asexual processes in the three orders and show, first, why the Leptomitales, while allied to the Saprolegniales through the formation of similar types of zoösporangia, can not be included with them.

Throughout the Saprolegniales typical zoösporangia are formed commonly and abundantly. The zoöspores are biciliate and diplanetic. In the Leptomitales there are also abundant zoösporangia and the zoöspores are likewise biciliate. However, a further comparison will show that the behavior of the zoöspores is not entirely alike in the two orders. The zoöspores in the Leptomitales are monoplanetic instead of diplanetic. As far as known this is true of all of the genera excepting Leptomitus and Apodachlya. Hence one of the arguments for including the family Leptomitaceae in the Saprolegniales on the basis of analogous zoösporangia does not hold good in its entirety. The condition of diplanetism is usually considered to represent a higher degree of specialization than is expressed by monoplanetism. Whether this be true or not does not alter the fact that the asexual reproductive processes in the two orders, though somewhat comparable, exhibit fundamental differences. If the question of including the Leptomitaceae in the Saprolegniales depended entirely on this one matter of zoöspore behavior, it probably would lose some of its significance, but when to this is added the segmentation of the hyphae and the presence of oögonia containing single oöspores with periplasm, we have important reasons for believing that the family Leptomitaceae should be placed in a distinct order and that it does not have a close relationship with the Saprolegniaceae.

In the asexual processes in the Peronosporales and Leptomitales we find even greater differences than those mentioned above. In the Peronosporales asexual reproduction may take place by means of conidia which germinate 
through formation of one or more germ tubes. In the genus Phytophthora and elsewhere the conidia are capable under certain conditions of functioning as zoösporangia. To be sure, these conditions may be commonly present but this does not invalidate the point just made. In the genus Pythium there is abundant evidence, as Butler (4) has pointed out, for believing that the zoösporangia and conidia are homologous. The same view doubtless applies to other genera in the Peronosporales. In some of the land-inhabiting pythiums conidia may be formed almost exclusively, while on other water-inhabiting species only zoösporangia are produced. Further proof of the homology of these two organs is given by the fact that a mere change in external conditions can determine whether the organ shall function as a conidium or as a zoösporangium (4). However, in the genus Peronospora the potentiality for developing in either direction has been practically lost. Hence one can say, physiologically speaking, that the usual means of asexual reproduction in the whole order is by conidia. In the Leptomitales asexual reproduction is exclusively by means of zoöspores formed in typical sporangia. These organs have never been known to function as conidia. This is possibly due, in part, to the fact that all of the fungi included in this order are water-inhabiting and hence have never developed the conidial condition so often associated with fungi parasitic on land plants. Until we are able to study these forms intensively in culture, we can not know whether or not the conidial condition may be induced under certain circumstances. Since such types of asexual conidia are not known to occur anywhere in the Leptomitales, it would be illogical to combine the two orders Peronosporales and Leptomitales. The relationships that do exist are based on other morphological grounds.

Asexual reproduction in certain of the Oömycetes may take place by the production of gemmae or chlamydospores as well as by zoösporangia or conidia. Butler defines a gemma in Pythium as a "vegetative bud representing a portion of the mycelium containing within itself a sufficient store of reserve nutrient to enable it to withstand isolation from the plant without losing its power of renewed growth." He followed Maurizio (24) in considering the gemmae, as just described, to be peculiar to the genus Pythium and not comparable to the "gemmae" known in the Saprolegniales. The presence of gemmae in the Leptomitales, however, is unknown. What are loosely called "resting spores" are not equivalent to the gemmae (see morphological discussion in the present paper).

Turning now to a consideration of the sexual processes in the several orders it is clear that there are good evidences for claiming relationships between the Peronosporales and Leptomitales. In the Peronosporales and Saprolegniales the process is markedly different. In the Saprolegniales many oöspores without periplasm are commonly formed in each oögonium. This fact at once precludes any possibility of including in that order any fungi in which single oöspores with periplasm are formed-a condition found throughout the Leptomitales. 
In the sexual reproductive processes in both the Leptomitales and the Peronosporales only the one oöspore with periplasm is formed. This type of development was observed and described in the Peronosporales by de Bary (Io, II), Büsgen (3) and others. They recognized the presence of a specialized protoplasm in the central part of the oösphere which was surrounded by a layer of thinner protoplasm. The problem of the detailed structure and function of the oöplasm has been a favorite topic for cytological investigation. Some of the strongest evidence that there are homologies between the two orders has been derived from cytological studies on the genera Pythium, Phytophthora, Peronospora and Albugo in the Peronosporales, and on Araiospora in the Leptomitales.

A brief summary of the facts, so obtained, that are essential to this discussion center around the following points: (I) presence or absence of a fertilization tube; (2) methods of formation of the fertilization tube; (3) presence of a receptive papilla on the ooggonial wall; (4) formation of a central body in the oösphere; (5) development of the protoplasm into oöplasm and periplasm.

Concrete instances will now be examined which have resulted from cytological and morphological studies and which show why there is strong evidence for believing that the Leptomitales and Peronosporales are related, even though (for the other reasons previously discussed) they can not be united.

Early morphological investigations had shown that in the Peronosporales definite fertilization tubes of antheridial origin are formed ( 8 , I I). Later cytological studies confirm this and actual fertilization also has been established. For this data we depend upon the substantial cytological contributions on Peronospora by Wager (37) and Whetzel (38), and on Albugo by Stevens (29) and Davis (9). The presence of fertilization tubes of just such undoubted antheridial origin are also clearly present in Rhipidium and Sapromyces in the Leptomitales. In Rhipidium europaeum and in $R$. americanum the fertilization tubes are plainly seen inside of the oögonia extending into the dense protoplasm at the center. After the periplasm has contracted to form the exospore, the tube stands out distinctly in sharp relief. Thaxter describes and figures (33) a similar condition for Sapromyces androgynous, and von Minden (25) gives ample proof of fertilization tubes of this nature in $S$. Reinschii.

King (18) working on Araiospora pulchra failed to find a fertilization tube of the type just mentioned, but describes and figures a definite tube which is formed entirely by the oögonium. While the formation of a tube in exactly this manner is quite unlike anything known in any other Phycomycetes, King remarked that in Albugo a similar modification is found in which the oögonium seems to take some part in the formation of the fertilization tube (36).

In all the cases known in the Leptomitales, the antheridial tubes enter 
at definite places on the oögonial wall, but not necessarily at any specialized area on the wall. In Sapromyces, Thaxter (34) states that the wall at the apex of the oögonium becomes indented by the antheridium. This is the nearest approach to a receptive papilla such as has been reported for several species of Albugo by Stevens (29) and Davis (9). However, a receptive papilla, or even a definite area on the oögonial wall through which the fertilization tubes enter, is generally lacking in the Saprolegniaceae. Butler (4, p. 52) claims that receptive papillae are present in A phanomyces spp.

Still another morphological character common to the two orders Peronosporales and Leptomitales is the formation in certain species of a differentiation in the oöplasm itself. Such a specialized part found in species of Albugo and called the central body by Wager (36), and the coenocentrum by Stevens (29), is supposed to consist of trophoplasm which functions in uniting the two gametes. A similar structure was again described in great detail for Araiospora pulchra by King (I8).

The last and most important of all of the evidence submitted concerns the presence of periplasm in the oögonium during and after oögenesis. It is unnecessary to describe here its appearance in the ooggonia, as that has already been done adequately by many investigators. It is sufficient to state that, as far as it is known, the oögonia in all or nearly all of the genera in the Leptomitaceae (33), Pythiaceae (4), Peronosporaceae (36), and Albugoniaceae (29), produce such a differentiation of protoplasm during the formation of the oöspore. It is in all probability much alike in its nature and function in all of these families. After fertilization the periplasm seems to disappear or to be altered and sometimes it forms what is commonly called the roughening of the exospore. In certain genera it forms radiating strands between spore and oögonial wall and becomes so characteristic a feature that it can be used as a good generic character. This has been done in describing the genera Rhipidium and Araiospora. In the former the periplasm later contracts and forms a ridged stellar layer on the exospore while in Araiospora the strands persist and form a single row of cell-like chambers surrounding the oöspore.

Still another characteristic by which the Leptomitales are distinguished from the Saprolegniales and Peronosporales is by the presence of constrictions in the hyphae. Associated with the constrictions are the pseudosepta which were early a source of interest to botanists. The pseudo-septa are composed of "cellulin," a substance so named by Pringsheim. It gives a negative reaction with the usual tests for fungus cellulose. The presence of these pseudo-septa was later made one of the chief characterizations of the Leptomitaceae. Thaxter describes these peculiarities of the family as a "segmentation of the hyphae through the presence of successive constrictions each corresponding to a pseudo-septum formed by a deposite of 'cellulin' (?) which nearly closes the passage from one segment to another except for a central perforation through which the protoplasm of the adjacent segment 
may usually be seen to be continuous." That distinction is retained as a character of the order Leptomitales. Although it is only a vegetative character, it is good additional evidence for keeping the Leptomitales apart from the other orders.

The facts here set forth show clearly that the Peronosporales and Leptomitales are allied in the character of their sexual reproductive organs, and that the Saprolegniales and Leptomitales are not closely allied in these traits. The segmentation of the hyphae also precludes a combining of the Leptomitales with either of the other two orders mentioned. The relationships throughout the whole group of Oömycetes are much more easily understood by accepting the order Leptomitales as a distinct order intermediate between the Blastocladiales and the Peronosporales.

The systematic relations within the family Leptomitaceae have been fully discussed by Thaxter $(31,32,33,34)$ and von Minden $(25,26)$ and need not be considered again here.

Another change affecting a portion of this group of water molds was made in 1910 by Petersen (27). At that time he established the order Blastocladiales. In it he placed his new family Blastocladiaceae with one genus, Blastocladia. That arrangement appears for the first time thereafter in von Minden's classification in 1916. The latter retained Petersen's arrangement and added Allomyces to that family. Such a classification does not meet all of the taxonomic difficulties in a satisfactory way, for it still leaves untouched some of the vexing problems pertaining to the relationships of the Leptomitaceae, Blastocladiaceae and Saprolegniaceae that have existed for a long time.

The Blastocladiaceae have, in common with the Saprolegniaceae, certain characteristics that seem to have been obscured by previous arrangements of the Phycomycetes. Such are the absence of periplasm in the formation of oöspores; the production of large numbers of zoöspores, and the absence of constrictions in the hyphae. It must be conceded that there are still gaps in the present arrangement of the groups so far discussed but these may become bridged more and more by the discovery of new forms. The fungi known at present do not provide an unbroken series, but nevertheless the evidence at hand seems to support the phylogenetic scheme just indicated.

The order Blastocladiales as here constituted follows the conception established for it by Petersen (1. c.). Within this family are found the fungi with characteristics making the transition from the Monoblepharidales reasonably clear. The chief characteristic of the order Monoblepharidales, namely the presence of motile antherozoids, is so unique that from the present data neither the Leptomitales nor the Blastocladiales could be combined with it.

This classification is based largely upon vegetative and asexual reproductive processes and is subject to modification whenever sufficient evidence 
warrants a change. Our lack of data concerning the sexual reproductive processes makes necessary the use of other facts in formulating a systematic scheme. Nevertheless, that basis of classification is recognized as having phylogenetic significance in such plant groups as the algae, and should be rated accordingly here.

The organization of the Blastocladiaceae differs in several respects from any previous arrangement. In addition to Blastocladia and Allomyces, the genus Gonapodya has been included and a new genus, Mindeniella, has been added.

The family so constituted reëmphasizes the close relationship between that family and the Monoblepharidaceae. Butler (5) gave an excellent discussion of the relations between the three genera Gonapodya, Blastocladia and Allomyces and their relation to Monoblepharis, without considering Petersen's new order, which had appeared only a short time previously. He placed the first three genera in the Leptomitaceae, but regarded them as a special group in that family.

The genus Gonapodya is included chiefly because of its non-cellulose walls, and because its zoöspores possess a fluctuating number of cilia, frequently one.

The genus Mindeniella exhibits most of the characters just mentioned, but differs in having membranes of cellulose composition and in having the sporangia and oögonia supported on pedicels. Its strongest alliances with the family lie in the general habit of growth, the lack of definite constrictions, the lack of periplasm and the large zoösporangia producing large numbers of zoöspores. It is probably one of the connecting links between the Blastocladiales and the Leptomitales.

Pythiomorpha ${ }^{2}$ clearly differs from the Leptomitales by the lack of constricted hyphae and cellulin plugs; and from the Blastocladiales by its biciliate, diplanetic zoöspores and filamentous thallus. It is evidently more closely related to Pythium by its biciliate zoöspores, filamentous thallus and similar mode of sexual reproduction, but differs decidedly in the structure of the mature sporangium, which lacks a tube or specialized beak such as occurs in the sporangia of all of the species of Pythium. Moreover the zoöspores do not form in an exterior vesicle as in that genus. They are also truly diplanetic, whereas in most of the species of Pythium the zoöspores are monoplanetic or have a specialized diplanetism (4).

Stevens (30), influenced by Fitzpaterick's view (12), has extended the limits of the Pythiaceae to include the three genera Pythium, Pythiocystis and Phytophthora. With this modification of Schröter's conception of the Pythiaceae, the family takes on a much more important place in the classification, and stands out in clearer contrast with the Albuginaceae and Pero-

2 A paper by Christine Johanna Buisman (Root rots caused by Phycomycetes. Haarlem, F. P. Visser, I927) appeared after this paper went to press. It is plain that Miss Buisman has not given sufficient attention to the characters of the genus Pythiomorpha or she would not suggest placing that genus with Phytophthora on the slight evidence which she presents. 
nosporaceae. Stevens' arrangement is unsupported by any accompanying remarks or discussion, but appears to be a step toward a more logical and lucid system within the Peronosporales. The purely physiological facts known for the species of the genera Phythophthora and Pythium set them off from the downy mildews as such. The saprophytic life, for example; which the species of these two genera can lead, in itself binds them together in contrast to the more fixed parasitism of the genuine downy mildews.

With this newly extended conception of the limits of the Pythiaceae, it at once becomes clear that Pythiomorpha gonapodioides has many things in common.

In a previous paper (I6) it was shown that under the then existing taxonomic arrangements, Pythiomorpha properly belongs in the family Pythiomorphaceae erected for it by Petersen (27). If we accept the introduction of Phytophthora into the Pythiaceae and the widening of the gate to that family in order to permit its entrance, than it is equally possible to lead the genus Pythiomorpha into the same fold, and Petersen's family becomes superfluous. Without deciding the status of Pythiocystis any further than was done by Stevens, the Pythiaceae are here considered to include Pythium, Pythiocystis, Phytophthora and Pythiomorpha as well as von Minden's Pythiogeton.

The relationship of Pythiomorpha gonapodioides seems closer to Phytophthora than to the genus Pythium. As already indicated it differs in three important particulars from Pythium; from Phytophthora it differs in its diplanetic zoöspores, in the absence of any conidial stage, and in its proliferating sporangia. In other characters it shows clearly its affinity with the Peronosporales as a group. The sexual organs, the mode of fertilization, and the presence of oöplasm and periplasm in the developing oögonium are equivalent to those of that order. On the other hand, there is little doubt that it shows considerable relationship to the Leptomitales, and it perhaps represents a connecting link with that group.

\section{SUMMARY}

I. By a study of more than half of the species of the Blastocladiaceae, Leptomitaceae, and Pythiomorphaceae now known, a rearrangement of the fungi belonging in these groups has become necessary and a new phylogenetic classification is here presented.

2. A new order, the Leptomitales, is shown to maintain a phylogenetic position between the Blastocladiales on the one side and the Peronosporales and Saprolegniales on the other side.

3. A new genus, Mindeniella, has been discovered, studied and described, and its position in the Blastocladiaceae determined.

4. Five new species have been found and described: Mindeniella spinospora, Blastocladia gracilis, Blastocladia tenuis, Blastocladia globosa, and Rhipidium parthenosporum. 
5. In Pythiomorpha gonapodioides, which was a part of this series of studies and an account of which has already been published (15), it has been shown that no vesicle is present at the time of the escape of the zoöspores. The sexual mode of reproduction in this species is for the first time definitely established.

6. Pythiomorpha is here shown to belong definitely to the Pythiaceae as emended by Stevens (30).

7. It is demonstrated that at least in one species of the Blastocladiales antheridia are formed, although hitherto male organs in this group had not been known to exist.

8. A study of the structure of the so-called "resting spores" in the genus Blastocladia, and the finding of antheridia in one species, has convinced the writer that such bodies are parthenogenetically formed.

9. The physiological experiments on the species belonging to the two genera Rhipidium and Blastocladia settle definitely the fact that these fungi require a special technique for their isolation into pure culture and that their reactions to environmental influences during development make necessary a decidedly different technique than that hitherto employed in obtaining pure cultures of the members of the Saprolegniaceae.

Io. An improved method is described for collecting some of these aquatic fungi.

II. It is demonstrated that these forms are everywhere, and for the most part abundantly, present in our lakes, rivers, ditches, and ponds.

I2. It is shown that these fungi can be kept and developed in rough cultures for long periods and that the plants that thrive under such conditions are, as far as can be determined, developed in a normal and healthy manner.

13. With all the new facts at command, it has seemed desirable to present these groups in an up-to-date monographic form, and to provide artificial keys.

The author takes pleasure in acknowledging her indebtedness to Professor C. H. Kauffman, who suggested the problem and gave generous advice and encouragement throughout the progress of the work.

DePaRTMENT OF Botany, UNIVERSITY OF MichigaN

\section{LITERATURE CITED}

I. Barrett, J. T. The development of Blastocladia strangulata n. sp. Bot. Gaz. 54: 353-370. 1912.

2. - - Development and sexuality of some species of Olpidiopsis (Cornu) Fischer. Annals Bot. 26: 209-238. 1912.

3. Büsgen, M. Die Entwickelung der Phycomycetensporangien. Jahrb. Wiss. Bot. 13: 253-285. I882.

4. Butler, E. J. An account of the genus Pythium and some Chytridiaceae. Mem. Dept. Agr. India. Bot. Ser. I, no. 5. 1907.

5. - On Allomyces, a new aquatic fungus. Annals Bot. 25: 1023-1034. I91 I. 
6. Coker, W. C., and Grant, F. A. A new genus of water mold related to Blastocladia. Jour. Elisha Mitchell Sci. Soc. 37: 180-182. 1922.

7. Coker, W. C. The Saprolegniaceae. Chapel Hill, North Carolina, I923.

8. Cornu, M. Monographie des Saprolégniées. Ann. Sci. Nat. Bot. V, 15: 5-198. 1872.

9. Davis, B. M. The fertilization of Albugo candida. Bot. Gaz. 29: 297-310. I900.

10. de Bary, A. Einige neue Saprolegnieen. Jahrb. Wiss. Bot. 2: I69-192. 1860.

11. - Untersuchungen über Peronosporeen und Saprolegnieen und die Grundlagen eines natürlichen Systems der Pilze. Beiträge zur Morphologie und Physiologie der Pilze 4: I-I 45 . I 88I.

12. Fitzpaterick, H. M. Generic concepts in the Pythiaceae and Blastocladiaceae. Mycologia 15: 166-I73. I923.

13. Hartog, M. M. On the cytology of the vegetative and reproductive organs of the Saprolegniaceae. Trans. Roy. Irish Acad. 30: 649-708. 1895.

I4. Humphrey, J. E. The Saprolegniaceae of the United States, with notes on other species. Trans. Amer. Phil. Soc. I7: 65-148. 1893.

15. Kanouse, B. B. Physiology and morphology of Pythiomorpha gonapodioides. Bot. Gaz. 79: 196-205. 1925 .

16. - - . On the distribution of the water molds, with notes on the occurrence in Michigan of members of the Leptomitaceae and Blastocladiaceae. Mich. Acad. Sci. Arts Lett. 5: 105-113. 1925 .

17. Kauffman, C. H. A contribution to the physiology of the Saprolegniaceae with special reference to the variations of the sexual organs. Annals Bot. 22: $361-386$. 1908.

18. King, C. A. Observations on the cytology of Araiospora pulchra Thaxter. Proc. Boston Soc. Nat. Hist. 3I: 21 I-245. 1903.

19. Klebs, G. Die Bedingungen der Fortpflanzung bei einigen Algen und Pilzen. Jena, 1896. (Review in Bot. Gaz. 23: 214-216. 1897.)

20. - - Zur Physiologie der Fortpflanzung einiger Pilze I, 2, 3. Jahrb. Wiss. Bot. 32: I-70; 33: 513-393; 35: 80-199. 1898-I900.

21. Kolkwitz, R. Zur Biologie von Leptomitus lacteus. Ber. Deutsch. Bot. Ges. 19: 288-291. I90I.

22. - - L Lber Bau und Leben des Abwasserpilzes Leptomitus lacteus. Mitteil. Königl. Prüfungsanstalt Wasserversorgung und Abwasserbeseitigung 2: 34-98. 1903.

23. - C C̈ber Bau und Leben des Abwasserpilzes Leptomitus lacteus. Ber. Deutsch. Bot. Ges. 21: 147-I 50. 1903.

24. Maurizio, A. Zur Entwickelungsgeschichte und Systematik der Saprolegnieen. Flora 79: IO9-I 58. I 894 .

25. von Minden, M. Chytridiineae, Ancylistineae, Monoblepharidineae, Saprolegniineae. Kryptogamenfl. Mark Brandenburg 5: 209-612. I912.

26. - Beiträge zur Biologie und Systematik einheimischer submerser Phycomyceten. Mykologische Untersuch. und Ber. 2: I46-254. I9I6.

27. Petersen, H. E. Studier over Ferskvands-Phycomyceter. Bot. Tidskr. 29: 345-429. 1909. (Engl. transl. Ann. Myc. 8: 494-560. 1910.)

28. Reinsch, P. F. Beobachtungen über einige neue Saprolegnieae, über die Parasiten in Desmidienzellen und über die Sachelkugeln in Achlyaschläuchen. Jahrb. Wiss. Bot. II : 283-3II. I 878 .

29. Stevens, F. L. Gametogenesis and fertilization in Albugo. Bot. Gaz. 32: 77-98; 157-169;238-26I. 1901.

30. - - Plant disease fungi. New York, 1925.

31. Thaxter, R. Observations on the genus Naegelia of Reinsch. Bot. Gaz. 19: 49-55. 1894. 


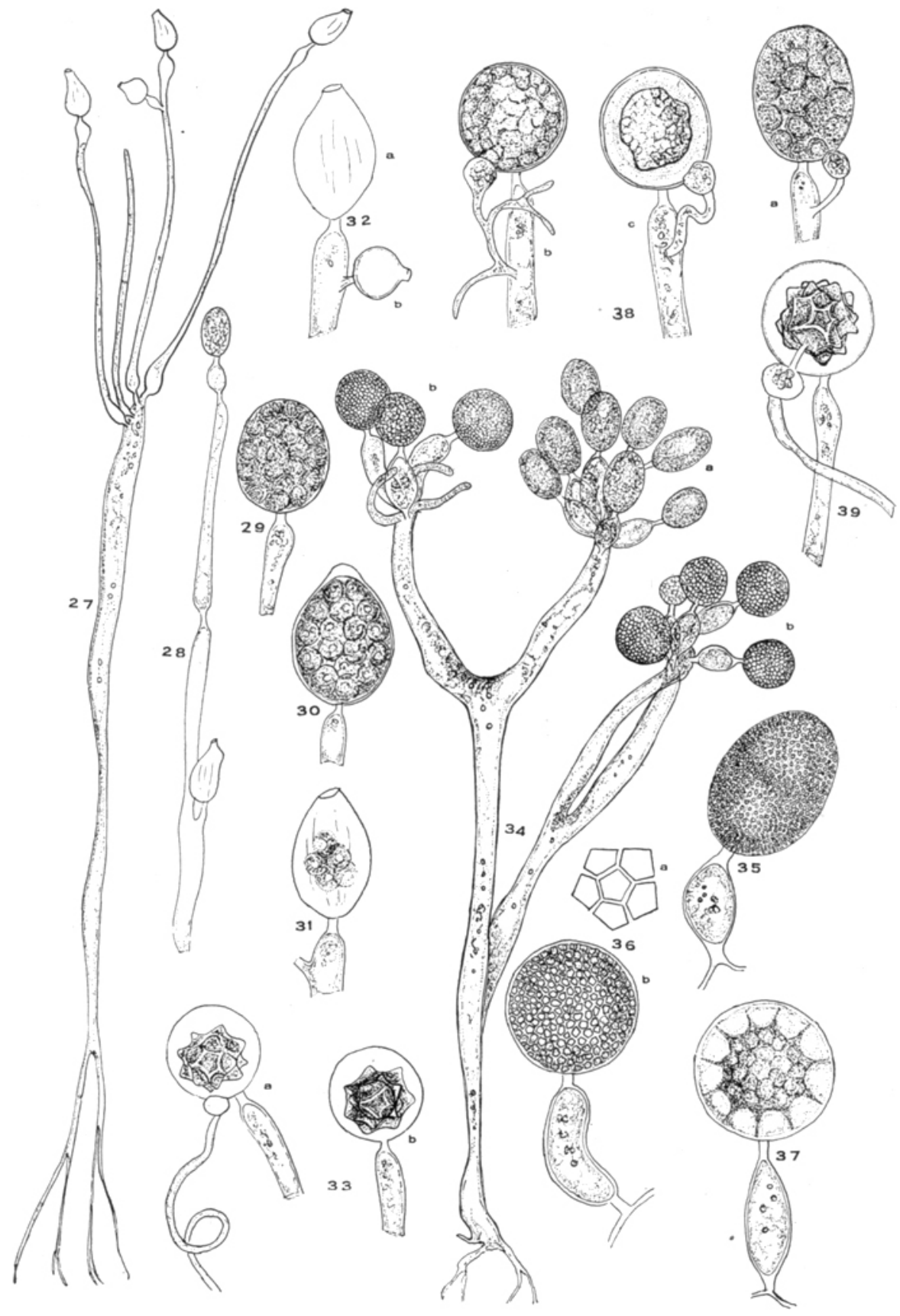

Kanouse: Water Molds 
32. - New or peculiar aquatic fungi 2. Gonapodya Fischer and Myrioblepharis nov. gen. Bot. Gaz. 20: 433-440, 477-485. 1895 .

33. - - New or peculiar aquatic fungi 3. Blastocladia. Bot. Gaz. 21: 45-52. 1896.

34. - New or peculiar aquatic fungi 4. Rhipidium, Sapromyces and Araiospora nov. gen. Bot. Gaz. 21 : 317-331. 1896.

35. Tiesenhausen, M. Beiträge zur Kenntnis der Wasser Pilze der Schweiz. Archiv. Hydrobiol. und Planktonkunde 7: 261-308. 1912.

36. Wager, H. On the structure and reproduction of Cystopus candidus Lév. Annals Bot. 10: $295-342$. I 896 .

37. - On the fertilization of Peronospora parasitica. Annals Bot. 14: 263-279. 1899.

38. Whetzel, H. H. A serious outbreak of onion blight. Cornell Univ. Agr. Exp. Sta. Bull. 218.1904.

\section{DESCRIPTION OF PLATE}

\section{Plate XlviII}

Figures 27-33, Rhipidium europaeum forma attenuata. Figures $34-37, R$. parthenosporum sp. nov. Figure $38, a, b$ and $c, R$. americanum. Figure $39, R$. europaeum.

Fig. 27. A whole plant.

FIG. 28. Branch taken from upper portion of plant shown in figure 27.

FIG. 29. Zoösporangium giving the appearance of the protoplasm before the spores are formed.

FIG. 30. Zoösporangium in which the spores are almost ready to be released. The papilla of dehiscence is plainly visible.

FIG. 3I. Sporangium from which a few spores failed to make their escape.

FIG. 32. A portion of a filament bearing two empty zoösporangia; $a$, a thin-walled sporangium; $b$, a thick-walled sporangium.

FIG. 33. $a$, an oögonium containing a mature oöspore. An antheridium of diclinous origin is seen attached to the oögonium. $b$, oögonium containing a mature oöspore.

FIG. 34. An entire plant terminated by whorls of short branches bearing reproductive organs. $a$, zoösporangia; $b$, oögonia.

FIG. 35. A zoösporangium in which the protoplasm is still in a very finely divided and evenly distributed condition.

FIG. 36. $a$, a detail of the arrangement of the protoplasmic contents in an early stage of the development of a sporangium; $b$, a stage in the development of a parthenospore.

FIG. 37. A later stage in the development in which the conspicuous protoplasmic strands radiating from the dense central mass to the oogonium wall are plainly visible.

FIG. 38. $a, b$ and $c$, ooggonia showing different stages in the development of the oöspore. Note the antheridia of androgynous origin. $a$, an early stage in the development of the oöspore in which the protoplasm is distributed evenly throughout the oögonium; $b$, a later stage in which a differentiation of the protoplasm is becoming visible; $c$, a still later stage in which the oöplasm and periplasm are distinct.

Fic. 39. An oögonium and antheridium. The oöspore is fully developed and is surrounded by the characteristic wall giving the spore an areolate appearance. The fertilization tube is evident. The antheridial branch is of diclinous origin. 